Brit. J. Ophthal. (1954) 38, 460.

\title{
POLYSACCHARIDE GRANULES IN ASSOCIATION WITH DEVELOPING RETINAL VESSELS AND WITH RETROLENTAL FIBROPLASIA
}

\author{
BY \\ GEOFFREY SERPELL \\ Department of Pathology, Institute of Ophthalmology, University of London
}

THE occurrence of polysaccharide in the retina has been known for some time, but there has been no uniformity of opinion as to its exact situation and functional significance. Glycogen has been described in the retina of the frog (Ehrlich, 1883; Brammertz, 1915; Schmitz-Moorman, 1927), the rabbit (Brammertz, 1915), the cat, and man (Kojima and Nagao, 1953), and in the rabbit retina after subcutaneous and intravitreal injection of dextrose (Nakashima, 1926). On the other hand, Best (1903) was unable to demonstrate this substance in the frog retina.

Until the introduction of the periodic acid-Schiff method, first used by McManus $(1946,1948)$ to demonstrate mucin histologically and subsequently elaborated into a histochemical technique for polysaccharide by Hotchkiss (1948), staining methods for identifying polysaccharides in tissues were empiric (Carpenter and others, 1951), as in the use of iodine (Bernard; see Creighton, 1896) and carmine (Best, 1906). With the application of the PAS method to the adult human retina, the internal limiting membrane, the peripheral portions of the rods and cones, and the basement membrane of the vascular tree were found to stain positively (Friedenwald, 1949; Day, 1950). In addition, intensely staining globules in the nerve fibre layer of degenerating retinae have been described by Day (1950).

In infants up to 2 years of age, Friedenwald (1949) showed that the retinal vascular basement membrane is much thinner and less easily seen than in adults; in the premature human infant, he found this basement membrane visible in the larger vessels only and not at all in the capillaries. Friedenwald concluded that it was not possible to say whether the membrane was nonexistent in foetal capillaries or merely so thin and delicate as to be invisible.

In the developing rabbit retina, Bembridge and Pirie (1951) described granules staining positively with PAS, which were found mainly in the inner retinal layers in the young rabbit between the eighth day and the end of the third week of life, but no relation to developing retinal vessels was reported. Compared with the human eye, the rabbit eye at birth is premature, in that the retina is not fully developed, the hyaloid vascular system still persists, and the lids are closed.

Recently, Kojima and Nagao (1953) have reported similar granules staining with PAS in the retinae of man and the cat, and Ashton (1954) has noted the occurrence of large numbers of PAS-positive granules in the retina in early retrolental fibroplasia. 
This latter observation stimulated the investigations recorded in this paper of the occurrence of polysaccharide in the developing human retina. These investigations were later extended to the kitten retina, in association with studies on the aetiology of retrolental fibroplasia (Ashton and others, 1953, 1954), and also to the retina of the young rabbit.

It was found that PAS-positive granules occur normally in association with proliferating mesenchymal cells in the developing retinal vasculature in man, the rabbit, and the cat, and pathologically in the retina in the early stage of retrolental fibroplasia in man and the kitten. The granules were found to consist of glycogen and their histochemical identification is described.

\section{Material}

(1) Early Retrolental Fibroplasia.-Thirteen eyes of seven cases of early retrolental fibroplasia.

(2) Live-born Premature Infants. -46 eyes of 27 infants of birth weight $1 \mathrm{lb} .3 \mathrm{oz}$. to $5 \mathrm{lb} .15 \mathrm{oz}$. and gestation period 26-36 weeks. Death was due to prematurity per se or associated pulmonary complications with an asphyxial mode of death in most cases.

(3) Live-born Mature Full-term Infants.-Four eyes from two infants were examined. Death was due to congenital heart disease in one instance, and to hydrocephalus in the other.

(4) Stillborn Premature Infants. -25 eyes of fourteen infants, one an anencephalic, were examined. The period of gestation ranged from 25 to 39 weeks.

(5) Stillborn Mature Full-term Infants.-Three eyes from two infants.

(6) Foetuses.-Seven were examined, one of 8 weeks' gestation period, three of 12 weeks', and one each of 16,18 , and 19 weeks' gestation.

(7) Rabbit.-A 14-day-old rabbit was examined, one eye being fixed in 10 per cent. formol saline and the other in Bouin's fluid.

(8) Kittens.- The retinae of several of the kittens used in experiments on the production of retrolental fibroplasia, described by Ashton and others (1954), were examined. Both normal kittens and those with new-vessel formation, induced by treatment with oxygen, were examined.

\section{Methods}

The specimens were all fixed in 10 per cent. formol saline, embedded in celloidin, and sectioned. Each specimen was stained with haematoxylin and eosin and by the periodic acid-Schiff method (PAS). In determining the nature of the granules, various polysaccharide stains and enzyme digestion studies were used:

(1) Differential Staining:

(i) PAS

(ii) Iodine

(iii) Toluidine blue

(iv) Best's carmine (v) Sudan black

(vi) Southgate muci-carmine

(vii) Schiff's reagent without previous treatment of the section with periodic acid.

To demonstrate the activity of the particular preparation of stain, a section rich in the substance for which the stain is specific was stained and examined, e.g. rabbit's liver (glycogen) was used for iodine and Best's carmine, cornea (mucopolysaccharide) for toluidine blue metachromasia, and conjunctival mucous secreting cells (mucin) for Southgate muci-carmine.

(2) Enzyme Studies

(i) Hyaluronidase.-The preparation used was "Rondase" (Evans), a form of mammalian testis hyaluronidase, and this was used with acetate buffer as described by Pearse (1953). 
(ii) Diastase.-Malt diastase (1 per cent.) in saline was used, a buffer not being required (Pearse, 1953).

In each case an active specimen and a boiled control were used, and both sections were subsequently stained with PAS.

A standard specimen of early retrolental fibroplasia (R.L.F.30 L.) was used for most of the experiments because of the much greater numbers of polysaccharide granules present. Identical tests were later applied to the retinae of normal human infants, the rabbit, and the kitten, thereby demonstrating the identity of the granules in these several species.

\section{Observations}

Granules of polysaccharide staining positively with PAS in the immature retina fixed in formol saline, are of varying size and purplish red in colour. They occur both intra- and extra-cellularly and are referred to below as $P A S$-positive granules. As far as possible, the distribution of the granules in the retinae is described according to the scheme illustrated in Fig. 1.
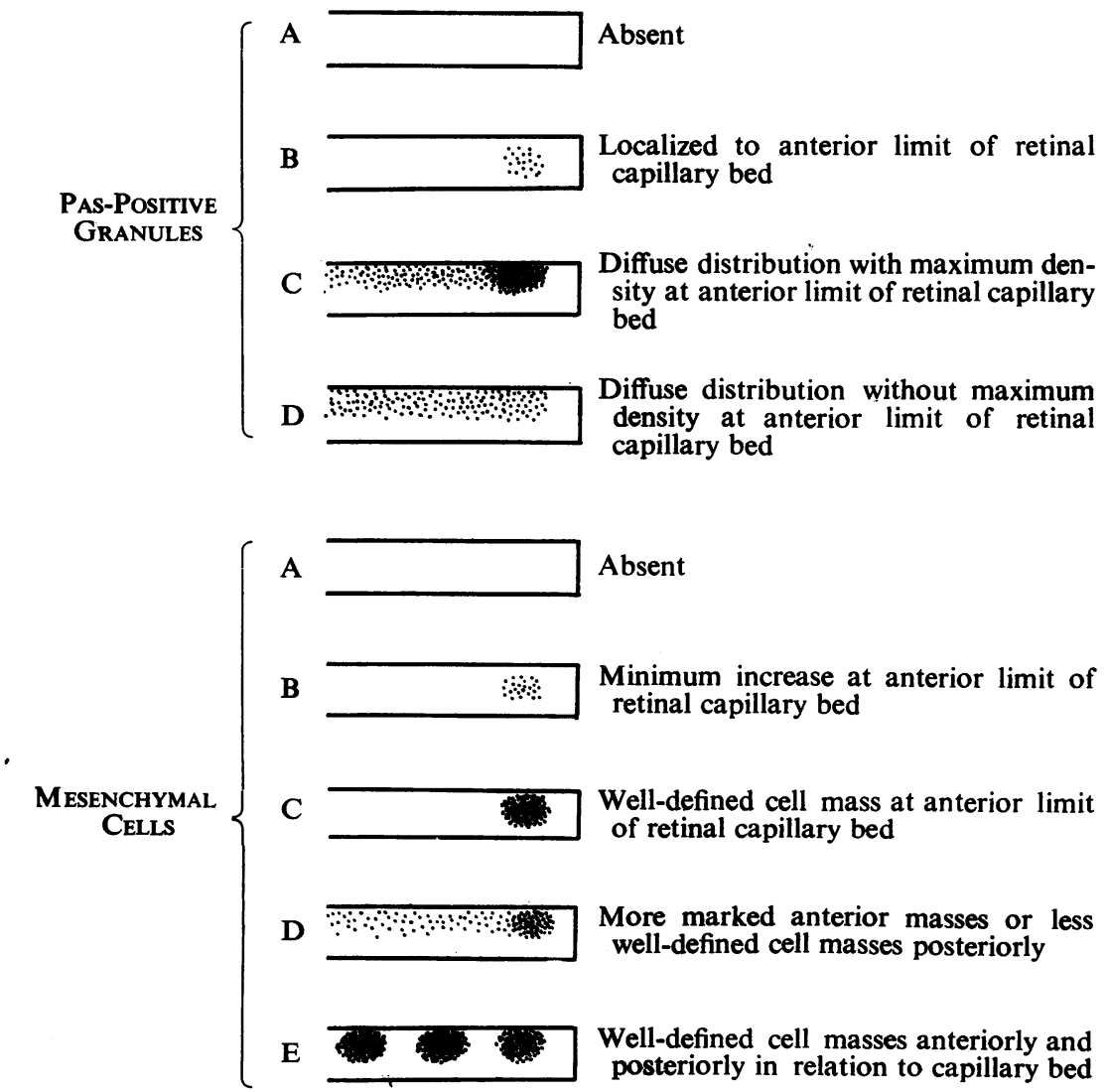

FIG. 1.-Classification of PAS-positive granule distribution and mesenchymal cell distribution. 
The nomenclature of the cells of mesodermal origin, constituting and associated with the developing retinal vascular tree, is confused. In previous accounts of the early histopathology of retrolental fibroplasia, the term " increased glial and endothelial cells" has been used. It appears that the cells with dark-staining nuclei of spindle shape, which were regarded as " glial cells ", are in fact cells of mesenchymal origin (Ashton, 1954). Larger cells with larger pale-staining nuclei are endothelial cells, and these are more intimately associated with canalized capillaries.

We have, therefore, described the actively proliferating cells (" glial cells ") as mesenchymal cells, and it will be shown that it is these particular cells which are associated with the presence of polysaccharide granules. As development of the retinal vessels proceeds in three planes, mesenchymal cell masses may occur anywhere in relation to the vascular tree; the distribution of cells is therefore described according to the scheme illustrated in Fig. 1.

\section{Occurrence of Polysaccharide Granules}

(1) Early Retrolental Fibroplasia.-Large numbers of PAS-positive granules were found in the inner retinal layers in intimate association with the areas of mesenchymal cell proliferation, as described by Ashton (1954) in the early stage of retrolental fibroplasia (Figs 2 and 3). The granules were found to be strictly intra-retinal in distribution, and where capillary buds grow out from the retina into the vitreous, whether canalized or not, granules were found only in the adjacent retina and not in association with the intravitreal out growths. Furthermore, the density of

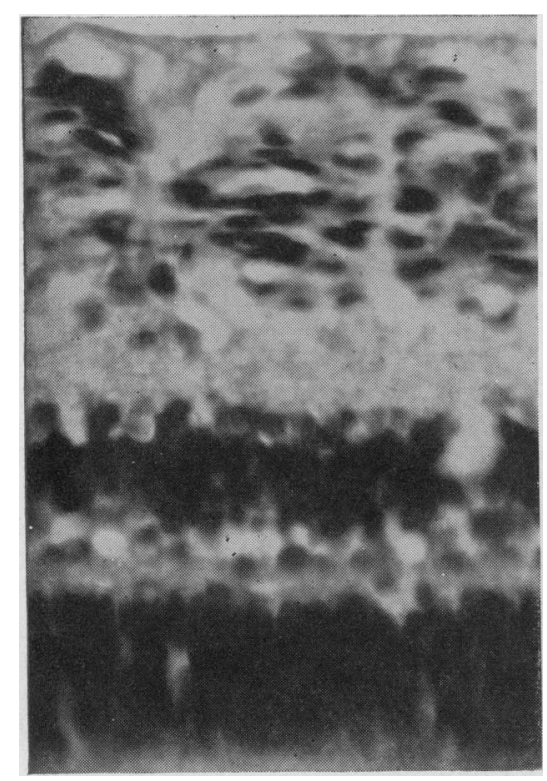

FIG. 2. - Early retrolental fibroplasia. High-power view of intraretinal mesenchymal cell masses (RLF $30 \mathrm{~L}$ ). Haematoxylin and eosin. $\times 500$.

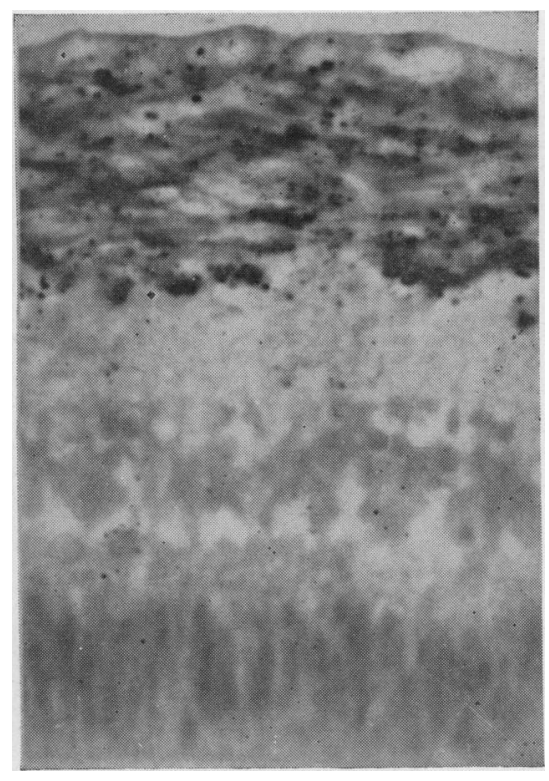

FIG. 3. - Early retrolental fibroplasia. High-power view showing relation of PAS-positive granules to mesenchymal cells in retina. (Cf. Fig. $2)$. PAS and haematoxylin. $\times 500$. 
granules was greater in relation to proliferating cell masses in the retina than to recently canalized newly formed vessels.

(2) Live-born Premature Infants.-The results are summarized in Tables I and II (see also Fig. 1). Of the 46 live-born premature infants' eyes, 76 per cent. showed an increase of mesenchymal cells, of varying extent in relation to the developing retinal vessels, and in 50 per cent. the cells were present as well defined masses (Fig. 4, opposite). Three retinae showed mesenchymal cells of Group E distribution; these are of particular interest in that the retinae are on the borderline between those with normally developing vessels and those showing the earliest changes of retrolental fibroplasia (Ashton, 1954; Ward, 1954).

TABLE I

INCIDENCE OF MESENCHYMAL CELLS AND PAS-POSITIVE GRANULES IN RETINAE OF LIVE-BORN PREMATURE INFANTS

\begin{tabular}{|c|c|c|c|c|c|}
\hline \multirow{2}{*}{ Distribution of Mesenchymal Cells } & \multicolumn{4}{|c|}{ Distribution of PAS-Positive Granules } & \multirow{2}{*}{ Tota } \\
\hline & A & B & $\mathrm{C}$ & $\mathrm{D}$ & \\
\hline $\begin{array}{l}\text { A } \\
\text { B } \\
\text { C } \\
\text { D } \\
\text { E }\end{array}$ & $\begin{array}{l}6 \\
1 \\
1 \\
0 \\
0\end{array}$ & $\begin{array}{l}2 \\
3 \\
1 \\
4 \\
0\end{array}$ & $\begin{array}{l}1 \\
4 \\
6 \\
5 \\
3\end{array}$ & $\begin{array}{l}2 \\
4 \\
2 \\
1 \\
0\end{array}$ & $\begin{array}{r}11 \\
12 \\
10 \\
10 \\
3\end{array}$ \\
\hline Total & 8 & 10 & 19 & 9 & 46 \\
\hline
\end{tabular}

TABLE II

INCIDENCE OF MESENCHYMAL CELLS AND PAS-POSITIVE GRANULES IN RETINAE OF LIVE-BORN PREMATURE INFANTS (PERCENTAGE)

\begin{tabular}{l|l|c}
\hline \multicolumn{1}{c}{ Formations } & \multicolumn{1}{c}{ Type of Distribution } & per cent. \\
\hline $\begin{array}{c}\text { Mesenchymal Cells } \\
\text { (76 per cent.) }\end{array}$ & (a) well-defined masses & 50 \\
\hline & $(b)$ minimal increase & 26 \\
\hline $\begin{array}{c}\text { PAS-Positive Granules } \\
\text { (83 per cent.) }\end{array}$ & $\begin{array}{l}\text { (a) localized to anterior limit of capillary bed } \\
\text { capillary bed }\end{array}$ & 22 \\
\cline { 2 - 3 } & $($ c $)$ diffuse distribution & 20 \\
\hline
\end{tabular}

PAS-positive granules were found in 83 per cent. of the live-born premature infants' eyes, Group C distribution being the commonest finding (Fig. 5, opposite).

Whatever the distribution of these granules, in no case were they found in front of the most anterior limit of the capillary bed, and when present, they were always found in the inner retinal layers, which are nourished by retinal capillaries.

(3) Live-born Mature Full-term Infants.-None of the four retinae examined (two cases) showed an increase in mesenchymal cells, and there was a complete absence of PAS-positive granules from the inner retinal layers. 


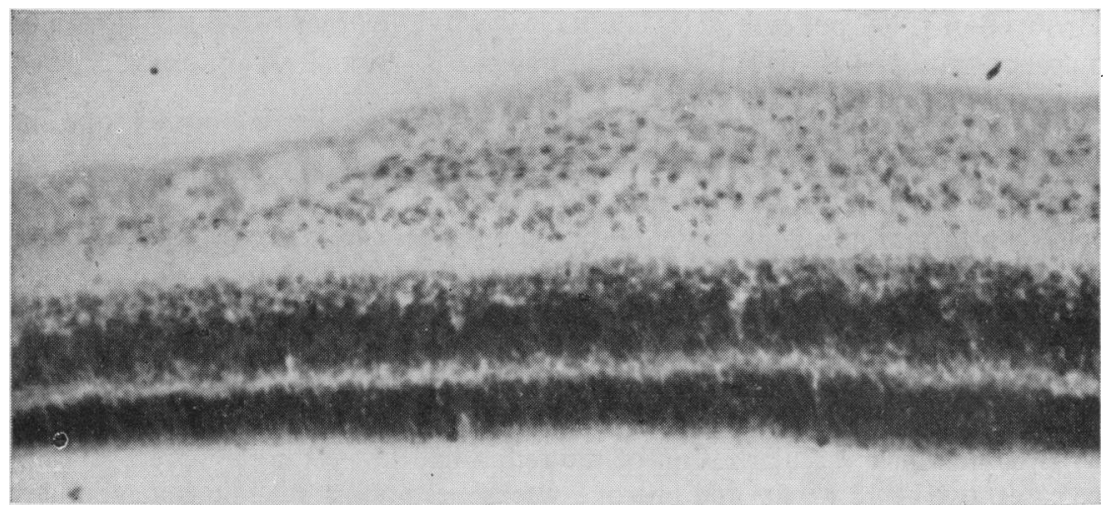

Fig. 4.-Retina of live-born premature infant (birth weight $2 \mathrm{lb} .6 \mathrm{oz} ., 32$ weeks' gestation), showing mass of mesenchymal cells at anterior limit of retinal vascular tree. Patent capillaries situated to right of cell mass, i.e. towards optic disc. $(\mathrm{PM} 110 \mathrm{~L})$. Haematoxylin and eosin. $\times 120$.

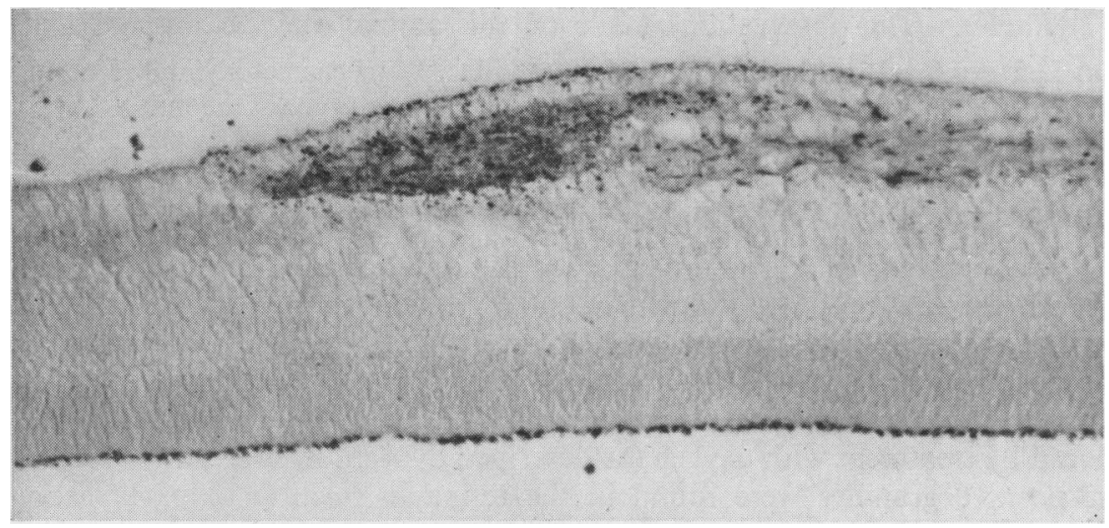

FIG. 5.-Retina of live-born premature infant (birth weight $2 \mathrm{lb} .6 \mathrm{oz} ., 32$ weeks' gestation), showing relation of PAS-positive granules to retinal capillaries. The greatest density of granules is in relation to the mesenchymal cell mass. (Cf. Fig. 4). $(\mathrm{PM} 110 \mathrm{~L})$. PAS. $\times 120$.

(4) Stillborn Premature Infants.-The results are summarized in Table III, which shows that 23 of the 25 eyes examined showed PAS-positive granule distribution

TABLE III

INCIDENCE OF MESENCHYMAL CELLS AND PAS-POSITIVE GRANULES IN RETINAE OF STILLBORN PREMATURE INFANTS

\begin{tabular}{c|c|c|c|c|c}
\hline \multirow{2}{*}{ Distribution of Mesenchymal Cells } & \multicolumn{2}{|c|}{ Distribution of PAS-Positive Granules } & \multirow{2}{*}{ Total } \\
\cline { 2 - 4 } & A & B & C & D & \\
\hline A & 0 & 0 & 0 & 0 & 0 \\
B & 2 & 3 & 7 & 0 & 12 \\
C & 0 & 5 & 7 & 0 & 12 \\
D & 0 & 1 & 0 & 0 & 1 \\
E & 0 & 0 & 0 & 0 & 0 \\
\hline Total & 2 & 9 & 14 & 0 & 25 \\
\hline
\end{tabular}


of Group B or C (92 per cent.). It is not clear why the other two retinae, with Group B mesenchymal cell distribution, contained no PAS-positive granules.

(5) Stillborn Mature Full-term Infants.-Of the three eyes examined, one showed no PAS-positive granules, although mesenchymal cells were present in masses (Group E), but poor fixation possibly explains this result. The other two eyes showed a minimal mesenchymal cell increase (Group B) with Group B distribution of PAS-positive granules. This is of interest since the retinae of live-born fullterm infants showed no PAS-positive granules.

(6) Foetuses.-The results of examining the retinae of seven foetal eyes may be summarized thus:

(a) Eyes in which vascularization of the retina had not yet commenced. There were three cases, two of 12 weeks' and one of 8 weeks' gestation. PAS-positive granules were not present in any of these retinae.

(b) Eyes in which vascularization of the retina had commenced. At the 12,16,18, and 19 weeks stages, all showed PAS-positive granules in relation to the developing retinal vessels the maximal density of granules being seen anteriorly.

(7) Rabbit.-The observations made on this animal may be summarized thus:

(a) Left eye fixed in 10 per cent. formol saline. With haematoxylin and eosin, welldeveloped retinal vessels were found, mainly on the inner surface of the retina. The rabbit has a membrana vasculosa retinae type of retinal circulation (Wolff, 1948). PAS-positive granules were present in the inner retinal layers in relation to the blood vessels.

(b) Right eye fixed in Bouin's fluid. No vessels were present in this specimen apart from a capillary at the equator. on one side, and no PAS-positive granules were present.

(8) Kitten.-In a 5-day-old normal control kitten (K4/2), PAS-positive granules distributed in a diffuse fashion were found in relation to the developing vessels. This observation was repeated in several other normally developing kittens.

In the kittens in which new vessel formation in the retina and vitreous had been induced by treatment with oxygen (as described by Ashton and others, 1953, 1954), PAS-positive granules were found in the retina in relation to proliferating cell masses but not in the vitreous. In addition, where they occurred intra-retinally, the density of the granules was greater in relation to proliferating cell masses than to newly formed canalized capillaries. These findings are similar to those described in early retrolental fibroplasia in man.

Of interest is the fact that, in kittens which died of infections and were found dead in the cage, the retinae showed evidence of post-mortem degeneration and no PASpositive granules were present.

\section{Nature of Polysaccharide Granules}

A summary of the histochemical observations made is given in Table IV (opposite) and Table V (overleaf). The significant findings are these:

(1) Granules staining with PAS.-These were found in the retina in early retrolental fibroplasia, in premature human eyes, in human foetal eyes (where vascularization had commenced), and in the eyes of new-born rabbits and kittens.

(2) Granules staining with Iodine.-These were found in the retina in early retrolental fibroplasia and in the 14-day-old rabbit.

(3) Diastase Lability of these Granules.-This was demonstrated in retrolental fibroplasia (Figs 6 and 7, opposite), in premature human eyes, and in the eyes of new-born rabbits and kittens. 
TABLE IV

DIFFERENTIAL STAINING OF POLYSACCHARIDE GRANULES (R.L.F. 30 L)

\begin{tabular}{l|l|l}
\hline \multicolumn{1}{c|}{ Stain } & \multicolumn{1}{|c}{ Observation } & \multicolumn{1}{c}{ Conclusion } \\
\hline PAS & $\begin{array}{l}\text { Large numbers of PAS-positive } \\
\text { granules in inner retinal layers } \\
\text { related to proliferating mesen- } \\
\text { chymal cells }\end{array}$ & $\begin{array}{l}\text { Granules are polysaccharide and } \\
\text { may be of the following nature: } \\
\text { glycogen, muco-polysaccharide, } \\
\text { glycoprotein, mucoprotein, } \\
\text { glycolipoid }\end{array}$ \\
\hline Iodine & $\begin{array}{l}\text { Most granules stained positively, } \\
\text { but fewer than with PAS }\end{array}$ & $\begin{array}{l}\text { Those which stain with iodine } \\
\text { are glycogen in nature }\end{array}$ \\
\hline Toluidine blue & No granules demonstrated & $\begin{array}{l}\text { Not mucopolysaccharide in } \\
\text { nature, e.g. hyaluronic acid, } \\
\text { ester-sulphuric acid }\end{array}$ \\
\hline Best's carmine & No granules demonstrated & Not glycogen in nature \\
\hline Sudan black & No granules demonstrated & Not glycolipoid in nature \\
\hline Southgate muci-carmine & No granules demonstrated & Not mucin in nature \\
\hline $\begin{array}{l}\text { Schiff's reagent without } \\
\text { previous treatment with } \\
\text { periodic acid }\end{array}$ & No granules demonstrated & No free aldehyde groups present \\
\hline
\end{tabular}

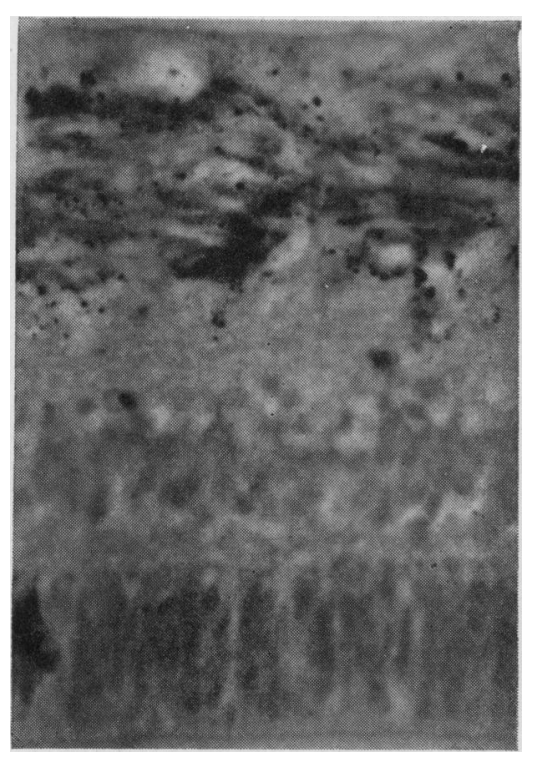

Fig. 6.-Enzyme study on RLF 30 L. Boiled diastase at $37^{\circ} \mathrm{C}$. for 24 hrs had no effect on the PAS-positive granules. PAS and haematoxylin. $\times 520$.

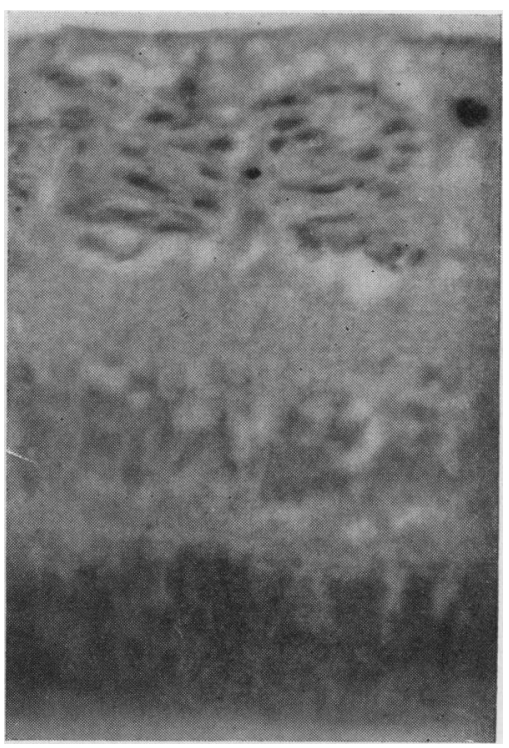

FIG. 7.-Enzyme study on RLF 30 L. Active diastase at $37^{\circ} \mathrm{C}$. for 24 hrs has removed PAS-positive granules from specimen (Cf. Fig. 6). PAS and haematoxylin. $\times 520$. 
TABLE V

ENZYME STUDIES

\begin{tabular}{|c|c|c|c|c|c|c|}
\hline Tissue & Enzyme & Buffer & $\begin{array}{l}\text { Temperature } \\
\left({ }^{\circ} \mathrm{C} .\right)\end{array}$ & $\begin{array}{l}\text { Time } \\
\text { (hrs.) }\end{array}$ & $\begin{array}{c}\text { PAS- } \\
\text { positive } \\
\text { Granules }\end{array}$ & Conclusions \\
\hline \multirow{2}{*}{ RLF 30L } & $\begin{array}{l}\text { HA } \\
\text { HB } \\
\text { HA } \\
\text { HB } \\
\text { HA } \\
\text { HB }\end{array}$ & $\begin{array}{l}\text { Acetate } \\
p \mathrm{H} 4.4\end{array}$ & $\left\{\begin{array}{l}37 \\
56\end{array}\right.$ & $\begin{array}{l}24 \\
48 \\
24\end{array}$ & $\begin{array}{l}+ \\
+ \\
+ \\
+ \\
+ \\
+\end{array}$ & $\begin{array}{l}\text { Granules hyaluronidase stable, } \\
\text { hence not mucopolysaccha- } \\
\text { ride in nature, i.e. hyaluronic } \\
\text { acid, or ester-sulphuric acid }\end{array}$ \\
\hline & $\begin{array}{l}\text { DA } \\
\text { DB } \\
\text { DA } \\
\text { DB } \\
\text { DA } \\
\text { DB }\end{array}$ & Saline & $\left\{\begin{array}{l}37 \\
56\end{array}\right.$ & $\left\{\begin{array}{l}24 \\
48 \\
24\end{array}\right.$ & $\begin{array}{l}\overline{+} \\
\overline{+} \\
\bar{t} \\
+\end{array}$ & $\begin{array}{l}\text { Granules diastase labile, hence } \\
\text { glycogen in nature }\end{array}$ \\
\hline PM $126 \frac{R}{L}$ & $\begin{array}{l}\text { DA } \\
\text { DB } \\
\text { DA } \\
\text { DB }\end{array}$ & $\begin{array}{l}\text { Saline } \\
\text { Saline }\end{array}$ & 37 & 15 & $\begin{array}{l}\bar{t} \\
\bar{t}\end{array}$ & $\begin{array}{l}\text { Granules diastase labile, hence } \\
\text { glycogen in nature }\end{array}$ \\
\hline$\underset{(L)}{\text { Rabbit }}$ & $\begin{array}{l}\text { HA } \\
\text { HB } \\
\text { DA } \\
\text { DB }\end{array}$ & $\left\{\begin{array}{l}\text { Acetate } \\
p \mathrm{H} 4.4\end{array}\right.$ & 37 & 5 & $\begin{array}{l}\dot{+} \\
\dot{+} \\
+\end{array}$ & $\begin{array}{l}\text { Granules hyaluronidase stable, } \\
\text { hence not mucopolysacchar- } \\
\text { ide in nature } \\
\text { Granules diastase labile, hence } \\
\text { glycogen in nature }\end{array}$ \\
\hline $\begin{array}{r}\text { Kitten } \\
(4 / 2)\end{array}$ & $\begin{array}{l}\text { HA } \\
\text { HB } \\
\text { DA } \\
\text { DB }\end{array}$ & $\left\{\begin{array}{l}\text { Acetate } \\
p \mathrm{H} 4.4 \\
\text { Saline }\end{array}\right.$ & 37 & 24 & $\begin{array}{l}+ \\
+ \\
+\end{array}$ & $\begin{array}{l}\text { Granules hyaluronidase stable } \\
\text { Granules diastase labile, hence } \\
\text { glycogen in nature }\end{array}$ \\
\hline
\end{tabular}

HA-Active hyaluronidase HB-Boiled inactive hyaluronidase DA-Active diastase DB-Boiled inactive diataste PAS-positive granules $\left\{\begin{array}{l}+ \text { present } \\ - \text { absent }\end{array}\right.$

RLF 30 L-Specimen of early retrolental fibroplasia PM $126 \mathrm{~L}$ and R-Premature human eyes

\section{Discussion}

Occurrence of Polysaccharide Granules.-An intimate association of polysaccharide granules with the developing retinal vasculature, particularly with the proliferating mesenchymal cells of this system, is the main point which emerged from this investigation. The evidence for this association of granules with the developing vessels is as follows:

(1) No granules are found in human foetal retinae before the retinal vessels begin to develop.

(2) No granules are found in the retina in front of the most anterior limit of the developing retinal capillary bed, i.e. between this limit and the ora serrata. This is most apparent in man, but is true also of the rabbit and kitten.

(3) The granules are found in the inner retinal layers which are nourished by the retinal vessels. This is most obvious in the rabbit where the capillaries are found in the optic nerve fibre layer only.

(4) Granules are not found in the retinae of live-born full-term infants or in adults. 
(5) At birth, neither the rabbit nor the kitten eye is mature, and PAS-positive granules occur in association with the developing retinal vessels at this stage of development in these animals.

(6) Because of the anatomy of the rabbit retina, no granules are found unless the section includes retinal vessels. The vessels are confined to the horizontal bands of medullated nerve fibres radiating into the retina from the optic disc.

In the development of the retinal vessels mesenchymal cell proliferation occurs with later differentiation to form the lining cells of capillaries. The particular association of the polysaccharide granules is with these proliferating mesenchymal cells; this is supported by the following evidence which emerges from the observations reported:

(1) Mesenchymal cells at the anterior limit of the retinal capillary bed are associated with the maximal density of polysaccharide granules. This is supported by two sets of results:

(a) In live-born premature infants (Table I), 23 retinae showed mesenchymal cells occurring as well-defined masses, i.e. of Group C, D, or E (Fig. 1). PAS-positive granules were present in nineteen of these retinae, showing Group B or C distribution (Fig. 1).

(b) Of 25 stillborn premature infants, a co-existence of mesenchymal cell increase and PAS-positive granules at the anterior limit of the retinal capillary bed was found in 23 (Table III). Similar observations were made on the 16, 18, and 19 weeks' foetuses.

(2) Mesenchymal cells other than those at the anterior limit of the vascular bed are associated with polysaccharide granules.

In the group of live-born premature infants (Table I), if the thirteen retinae showing Group D and E distribution of mesenchymal cells are considered together, PAS-positive granules of Group C and D (Fig. 1) were found in nine cases.

(3) Mesenchymal cell proliferations in early retrolental fibroplasia are associated with large numbers of polysaccharide granules in the retina.

Of interest in relation to early retrolental fibroplasia are the three retinae (Table I) showing Group E distribution of mesenchymal cells (Fig. 1). This histological picture merges imperceptibly into that of early retrolental fibroplasia. These three retinae showed Group C distribution of PAS-positive granules, i.e. a diffuse distribution with maximal density anteriorly (Table I). It is important that in retrolental fibroplasia the polysaccharide granules are related to intra-retinal mesenchymal cell proliferations: where invasion of the vitreous occurs, granules are found in the adjacent retina only.

It is thus clear that the essential relationship is between mesenchymal cells and polysaccharide granules, and that this secondarily determines the relationship of the latter to the developing retinal vessels.

Nature of Polysaccharide Granules.-Polysaccharides of varying types, which have been extensively studied histochemically, are widely distributed throughout plants and animals in association with many cellular activities (Pearse, 1949, 1953).

Histochemical observations recorded in this paper demonstrate that the granules associated with the developing retinal vessels consist of glycogen. Several points emerge from these observations for further discussion:

(1) All the granules were diastase labile and some stained positively with iodine. 
Histochemically, diastase lability is regarded as a more specific test for glycogen than the old empiric staining methods with iodine and Best's carmine (Pearse, 1953, and others). No explanation can be offered why the granules did not stain with Best's carmine or why only some stained with iodine (Table IV). Bembridge and Pirie (1951) found that polysaccharide granules in the rabbit stained with Best's carmine but not with iodine, and concluded that the retinal polysaccharide was glycogen. We agree with this, but the demonstration of diastase lability is more conclusive.

(2) All tests for other polysaccharides were negative.

(3) The appearance of the polysaccharide as granules in a tissue fixed in formol saline suggests its glycogenic nature.

Since Bernard (see Creighton, 1896) observed glycogen microscopically by using iodine, opinions have,varied as to its water solubility in tissues and hence as to the best method of fixation for its histochemical demonstration.

Bernard used a non-aqueous fixative and stained with an alcoholic iodine solution; on the other hand, Creighton (1896) used an aqueous iodine solution for staining material fixed in potassium bichromate and alcohol. Both authors described the glycogen as occurring in granular form.

Using the freeze-drying technique for fixation, Bensley and Gersh (1933) demonstrated a homogenous staining of cytoplasm, whereas with other methods, (e.g. chemical fixation with alcohol or formalin), various degrees of granularity were demonstrated with glycogen stains. This granular appearance is in fact an artefact (Gersh, 1932; Lazarow, 1942), and as our material was fixed in 10 per cent. formol saline, an explanation for the occurrence of the glycogen in granular form is apparent. With regard to the fixation of retinal glycogen in sections, Bembridge and Pirie (1951) state that formalin fixation did not preserve it as well as Bouin's fluid or 70 per cent. alcohol, and that this was probably due to the greater water content of the formalin (with loss of glycogen due to its water solubility). Kojima and Nagao (1953) also stated that alcohol fixation gave the best results. In our experience, however, fixation with 10 per cent. formol saline has been quite satisfactory. Recent work by Vallance-Owen (1948) and Carpenter and others (1951) has shown that formalin fixation followed by prolonged washing of the fixed block in water does not impair the staining of glycogen, and hence it appears that the water solubility of glycogen in the test tube is of no significance when glycogen in tissues is being considered. The water content of Bouin's fluid and of 10 per cent. formol saline is almost the same.

Significance of Glycogen Granules.-In any scheme of morphogenesis there are three components: cell proliferation and growth, differentiation of cells, and associated metabolic activity (Needham, 1942). Whilst the exact significance of glycogen granules is as yet unknown, it would appear that, in the development of the retinal vessels, their occurrence is an index of some transient metabolic activity. This is supported by observations of waves of mesodermal cell activity associated with glycogen granules inthe developing cornea, choroid, mesodermal iris, and pupillary membrane (Serpell, 1953).

A theory was put forward by Vastarini-Cresi $(1921,1924)$ that canalization of vessels and spaces is especially associated with glycogen metabolism. He stated that active cell proliferation to form buds was followed by glycogenic infiltration of the central cells of the bud. Later, cytolysis of these central cells occurred, resulting in the formation of a lumen. However, he did not indicate the exact metabolic significance of the glycogen.

Whilst these metabolic questions remain unanswered, the present study of glycogen in association with the developing retinal vessels provides an 
explanation of the polysaccharide granules found in the retina in early retrolental fibroplasia, which is essentially a disease process of the immature retinal vasculature.

\section{Summary}

(1) Polysaccharide granules have been demonstrated in association with areas of increased mesenchymal cell content in the inner retinal layers in the early stage of retrolental fibroplasia.

(2) Similar granules occur in relation to the developing retinal vessels in man, the cat, and the rabbit.

(3) The relationship of polysaccharide granules to the developing retinal vasculature depends essentially on their association with proliferating mesenchymal cells in the developing vascular bed.

(4) The granules have been identified histochemically as glycogen.

(5) The metabolic significance of the glycogen granules associated with developing retinal vessels is not yet determined.

I wish to express my thanks to Dr. Norman Ashton for help and encouragement in this investigation and for advice in the preparation of this paper. I am also indebted to Mr. A. Johnston and Mr. G. Knight for technical assistance, and to the Department of Medical Illustration at the Institute of Ophthalmology, for the photographs.

\section{REFERENCES}

Ashton, N. (1954). British Joural of Ophthalmology, 38, 385.

, WARD, B., and SERPELl, G. (1953). Ibid., 37, 513.

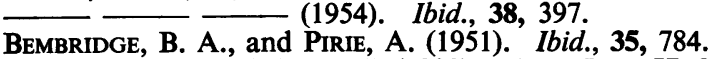

BensLeY, R. R., and GerSH, I. (1933). Anat. Rec., 57, 205, 217, 369.

BERNARD, C. Quoted by Creighton (1896).

BEST, F. (1903). Beitr. path. Anat., 33, 585. (Quoted by Cameron, 1952). (1906). Z. wiss. Mikr., 23, 319.

Brammertz, W. (1915). Arch. mikr. Anat., 86, 1. (Quoted by Bembridge and Pirie, 1951).

CAMERON, G. R. (1952), "Pathology of the Cell ". Oliver and Boyd, Edinburgh.

Carpenter, A., Polonsky, B., and Menten, M. L. (1951). Arch. Path. (Chicago), 51, 480.

CREIGHTON, C. (1896). "Microscopic Researches on the Formative Property of Glycogen ". Black, London.

DAY, R. (1950). Amer. J. Ophthal., 33, 224.

EHRLICH, B. (1883). Cited by Frerichs (1883).

FRERICHS, F. T. (1883). Z. klin. Med., 6, 33.

FriEDENWALD, J. S. (1949). Amer. J. Ophthal., 32, 487.

GerSH, I. (1932). Anat. Rec., 53, 309.

HotchKiss, R. D. (1948). Arch. Biochem., 16, 131.

KoJiMA, K., and NAGAO, Y. (1953). Acta soc. ophthal. jap., 57, 127. (Ophthal. Lit. (Lond.), 7, 94).

LAZAROW, A. (1942). Science, 95, 49.

MCMANUS, J. F. A. (1946). Nature, 158, 202. (1948). Stain Technology, 23, 99.

NAKashima, C. (1926). v. Graefes Arch. Ophthal., 116, 403. (Quoted by Bembridge and Pirie, 1951).

NeEDHAM, J. (1931). " Chemical Embryology ". University Press, Cambridge.

NEDHAM, (1942). "Biochemistry and Morphogenesis". University Press, Cambridge.

Pearse, A. G. E. (1949). J. clin. Path., 2, 81.

PEARSE, (1953). " Histochemistry". Churchill, London.

Schmitz-Moorman, P. (1927). v. Graefes Arch. Ophthal., 118, 506.

SERPELl, G. (1953). Personal observations.

VAllanCe-OWen, J. (1948). J. Path. Bact., 60, 325.

VASTARINI-CreSI, J. (1921). Atti. Accad. Med.-Chir. Napoli., 75, 1.

- (1924). Arch. ital. Biol., 73, 97.

WARD, B. (1954). British Journal of Ophthalmology, 38, 445.

WOLFF, E. (1948). " "The Anatomy of the Eye and Orbit", 3rd ed. Lewis, London. 